O.V. Sumariuk, V.F. Romankevych, O.D. Halunka, O.V. Kutsyk, V.V. Polevetsky, S.M. Novikov, I.M. Fodchuk

\title{
Influence of Polyfunctional Nanomodificators on the Microstructure of Concrete Composites of High Strength and Density
}

\author{
Yuriy Fedkovych Chernivtsi National University, Chernivtsi, Ukraine, e-mail: ifodchuk@ukr.net
}

\begin{abstract}
The patterns of formation of highly functional concretes structure, which consist in formation of an ordered, low-porous, fine-crystalline microstructure of cementitious matrix, in particular due to pozzolanic reactions of the non-clinker part of the binder with formation of an additional amount of low-basic hydrocarbons, are investigated.
\end{abstract}

Keywords: concrete, ultrafine modifiers, silica, metacaolin, quartz powder, scanning electron microscopy.

Received 26.02.2020; accepted for publication 15.03.2020.

\section{Introduction}

When obtaining high strength concrete composites, an important characteristic is the density of filling at the micro- and nanostructural level. Among the technological factors that influence the formation of a concrete matrix of high structural strength and density there are, as a rule, modification of the composite by a complex of finely dispersed modifiers based on amorphous condensed silica with a specific surface area of $\approx 250 \mathrm{~m}^{2} / \mathrm{g}[1-7]$.

In works [3-5] it is shown that the structure of highstrength concrete is formed mainly of low-basic calcium silicate hydrates (CSH-I). At the same time, there are a number of factors that can affect the physical and mechanical properties of concrete. These are microcracks, caused by autogenous shrinkage, which significantly reduces the resistance of concrete to corrosive media, and defects in the interphase transition region between the cement matrix and aggregate fillers [8-10].

Mechanisms and dynamics of structural changes of physicochemical processes, occurring in concrete composites with the introduction of superplasticizers, require complex studies. High-resolution X-ray diffractometry, atomic force microscopy and secondary ion mass spectrometry methods provide this opportunity
[11-14]. This is due to the fact that a number of physical problems regarding the structural characteristics of the studied crystals with a large number of uncontrolled impurities and their role in the formation of the ultrahigh-strength concrete structure remain unknown [15].

In this article, the mechanisms of structure formation in concrete composites modified with fine additives of microsilica (MS) and metakaolin (MTK), whose compressive strength exceeds $120 \mathrm{MPa}$, are investigated. The methods of X-ray structural analysis, X-ray spectral analysis and scanning electron microscopy were used to determine the composition and products of hydration.

\section{Objects of research}

Two experimental composition № 1 and № 2 of concrete compound with compressive strength of $50 \mathrm{MPa}$ and $120 \mathrm{MPa}$, respectively, were selected to study the processes of structure formation in concrete composites and their effect on the strength indices. In particular, the optimal polyfractionation mixture based on the analysis of the equations of the perfect FAFD curves is selected for composition №1, and which can provide the densest packing of the composite [16]. For composition №2 the mixture is modified by finely dispersed modifiers based on MS and MTK $[4,5]$. According to these recipes, we made a set of 10x10x10 cm samples, which were stored 
O.V. Sumariuk, V.F. Romankevych, O.D. Halunka, O.V. Kutsyk, V.V. Polevetsky, S.M. Novikov, I.M. Fodchuk

Table 1

The distribution of the main elements of the cement matrix of composition № 1 (Fig. 1,a)

\begin{tabular}{|c|c|c|c|c|c|c|c|c|c|}
\hline \multirow{2}{*}{ Region } & $\mathrm{C}$ & $\mathrm{O}$ & $\mathrm{Mg}$ & $\mathrm{Al}$ & $\mathrm{Si}$ & $\mathrm{K}$ & $\mathrm{Fe}$ & $\mathrm{Ca}$ \\
\cline { 2 - 9 } & \multicolumn{7}{|c|}{$\%$} \\
\hline 1 & 2.52 & 40.30 & 0.57 & 1.78 & 13.38 & 0.49 & 1.74 & 39.23 \\
\hline 2 & 6.54 & 36.56 & 0.59 & 0.43 & 12.34 & - & - & 43.54 \\
\hline 3 & 20.32 & 42.05 & - & - & 37.18 & - & - & 0.45 \\
\hline 4 & 18.40 & 40.61 & - & - & 40.19 & - & 0.34 & 0.46 \\
\hline 5 & 21.33 & 37.56 & 0.70 & 1.8 & 17.81 & 0.8 & 1.30 & 18.69 \\
\hline 6 & 21.66 & 38.90 & 0.71 & 2.15 & 18.44 & 0.92 & 1.01 & 16.20 \\
\hline 7 & 19.06 & 40.28 & 0.54 & 1.37 & 23.64 & 0.58 & 0.8 & 13.74 \\
\hline
\end{tabular}

he distribution of the main elements of the cement matrix of composition № 2 (Fig. 2,a)

\begin{tabular}{|c|c|c|c|c|c|c|c|c|}
\hline \multirow{2}{*}{ Region } & $\mathrm{C}$ & $\mathrm{O}$ & $\mathrm{Mg}$ & $\mathrm{Al}$ & $\mathrm{Si}$ & \multicolumn{2}{c|}{$\mathrm{Fe}$} & $\mathrm{Ca}$ \\
\cline { 2 - 9 } & \multicolumn{7}{|c|}{$\%$} \\
\hline 1 & 11.51 & 46.05 & - & - & 42.24 & - & 0.20 \\
\hline 2 & 12.12 & 45.50 & - & - & 41.95 & - & 0.43 \\
\hline 3 & 17.15 & 42.85 & - & 0.18 & 38.98 & - & 0.55 \\
\hline 4 & 14.06 & 41.09 & 1.24 & 1.92 & 17.09 & 0.94 & 22.95 \\
\hline 5 & 9.37 & 45.89 & 1.00 & 2.92 & 21.94 & 1.13 & 17.09 \\
\hline 6 & 8.02 & 45.23 & 1.10 & 2.86 & 23.41 & 1.01 & 17.80 \\
\hline 7 & 20.28 & 40.69 & 0.40 & 1.53 & 26.38 & 0.80 & 9.34 \\
\hline
\end{tabular}

Table 3

Elemental composition of chip of concrete composition № 1 (Fig. 3,a)

\begin{tabular}{|c|c|c|c|}
\hline Element & Apparent Concentration & Wt\% & Standard Label \\
\hline $\mathrm{C}$ & 108.28 & 19.27 & $\mathrm{C}$ \\
\hline $\mathrm{O}$ & 285.15 & 44.50 & $\mathrm{SiO} 2$ \\
\hline $\mathrm{Na}$ & 5.13 & 0.45 & $\mathrm{Albite}$ \\
\hline $\mathrm{Mg}$ & 2.27 & 0.21 & $\mathrm{MgO}$ \\
\hline $\mathrm{Al}$ & 10.60 & 0.82 & $\mathrm{~A} 2 \mathrm{O} 3$ \\
\hline $\mathrm{Si}$ & 55.79 & 3.86 & $\mathrm{KBO} 2$ \\
\hline $\mathrm{K}$ & 19.90 & 1.07 & $\mathrm{~KB}$ \\
\hline $\mathrm{Ca}$ & 495.17 & 29.03 & $\mathrm{Fe}$ \\
\hline $\mathrm{Fe}$ & 10.54 & 0.79 & \\
\hline
\end{tabular}

Table 4

Elemental composition of chip of concrete composition № 2 (Fig. 4,a)

\begin{tabular}{|c|c|c|c|}
\hline Element & Apparent Concentration & Wt\% & Standard Label \\
\hline $\mathrm{O}$ & 393.92 & 50.40 & $\mathrm{SiO} 2$ \\
\hline $\mathrm{Na}$ & 3.87 & 0.34 & $\mathrm{Albite}$ \\
\hline $\mathrm{Mg}$ & 3.43 & 0.31 & $\mathrm{MgO}$ \\
\hline $\mathrm{Al}$ & 19.98 & 1.52 & $\mathrm{Al} 2 \mathrm{O}$ \\
\hline $\mathrm{Si}$ & 257.48 & 17.81 & $\mathrm{SiO} 2$ \\
\hline $\mathrm{S}$ & 12.53 & 0.90 & $\mathrm{FeS} 2$ \\
\hline $\mathrm{K}$ & 17.78 & 1.03 & $\mathrm{KBr}$ \\
\hline $\mathrm{Ca}$ & 439.97 & 26.75 & $\mathrm{Wollastonite}$ \\
\hline $\mathrm{Fe}$ & 12.70 & 0.94 & $\mathrm{Fe}$ \\
\hline
\end{tabular}

under normal conditions.

Samples of concrete composites after 28 days of exposure under normal conditions overcame the compressive strength of the composition: № 1 63.1 MPa; № 2 - $120 \mathrm{MPa}$. This strength level for concrete composite №2 exceeds that of high-grade concrete C100/115 (according to DIN EN 206-1/DIN 1045-2 [17]). The consistency of the concrete composition was determined by the Abrams cone [18]: for composition №1 it was $4 \mathrm{~cm}$, for № $2-9 \mathrm{~cm}$.
To obtain chips, samples were loaded continuously at a rate that ensures uniform stress in the sample until its deformation and complete destruction.

\section{Research Methods}

X-ray structural investigations of the composition of cement composite samples were performed on X'Pert PRO MRD diffractometer in a single-crystal set for 
$\mathrm{Cu} K_{\alpha 1}$ radiation. The samples were ground and in the shape of fine powder were sieved through a sieve with cell diameter $\sim 0.08 \mathrm{~mm}$. Experimental X-ray data were processed using Match3 software (http://www.crystalimpact.com/match).

Determination of the effects of different additives and their complexes on the formation of hydration phases and microstructures of chips of cement composite was performed using a scanning electron microscope "Zeiss" EVO-50 with CCD detector (Table 1 and 2). X-ray spectral microanalysis was performed using X-ray spectrum analyzer Link-860, Oxford IncaEnergy 450. At the same time, scanning electron microscope Hitachi SU 70 with $\mathrm{CCD}$ detector was used to analyze the microstructure of concrete chips. Elemental analysis was performed using energy dispersive X-ray spectroscopy (EDX) (Table 3 and 4).

Physical and mechanical studies of concrete samples were carried out in accordance with international standards DIN EN 197-1 [19]. Determination of compressive strength was carried out on the hydraulic press P250. The loading of the samples was carried out continuously at a speed $0.6 \pm 0.4 \mathrm{MPa} / \mathrm{s}$ that provides an increase in the sample stress until its complete destruction.
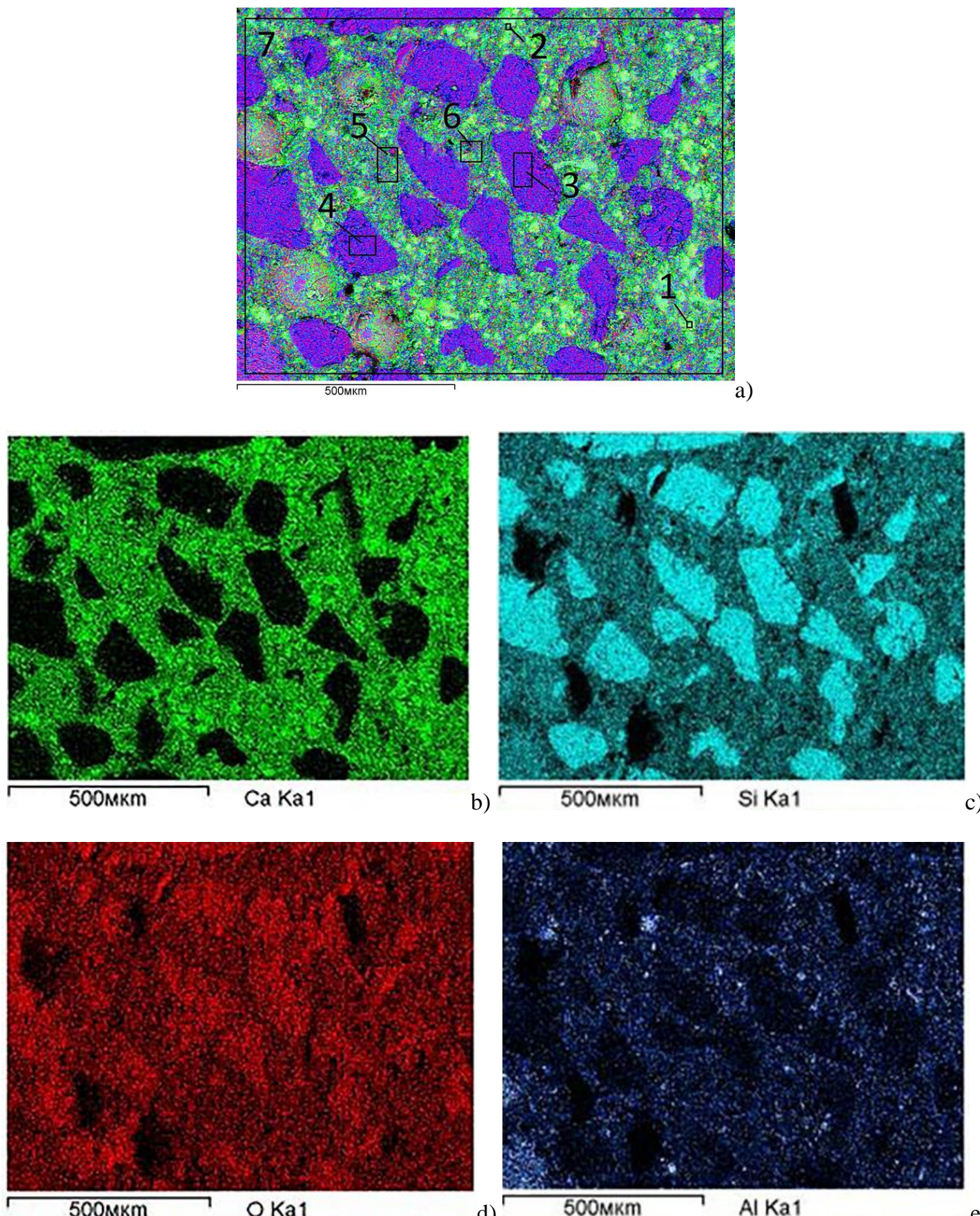

d)

$500 \mathrm{MKm}$

Al Ka1

e)

Fig. 1. Composition № 1. The content of chemical elements in the numbered regions (Table 1) on SEM images (a) and on the surface of chips of cement matrix: $\mathrm{Ca}(\mathrm{b}), \mathrm{Si}(\mathrm{c}), \mathrm{O}$ (d), $\mathrm{Al}(\mathrm{e}) .(\mathrm{x} 250)$. 
O.V. Sumariuk, V.F. Romankevych, O.D. Halunka, O.V. Kutsyk, V.V. Polevetsky, S.M. Novikov, I.M. Fodchuk

\section{Results}

Topograms, obtained by SEM (Fig. 1-4), show the relative content of elements (Table 1-4), which characterizes the phase composition in volume and on chip surfaces of numbered regions for samples of composition № 1 and № 2 .

The list of elements and their percentage indicates the presence in the concrete matrix of hydrosilicates and calcium aluminates, as well as calcium hydroxide. In local grains, the percentage of basic elements also coincides, in particular in grains 3 and 4 in Fig. 1a and grains 1,2 and 3 in Fig. 2a. At the same time, in the intergranular regions 1 and 2 (Fig. 1) there is significantly (twice) lower carbon content and higher (twice) calcium content than in the corresponding regions 5 and 6 in Fig. 2,a. However, the ratio of calcium to silicon is almost indistinguishable.

The microstructure of the chips differs significantly in scanning electron images. It is more developed and

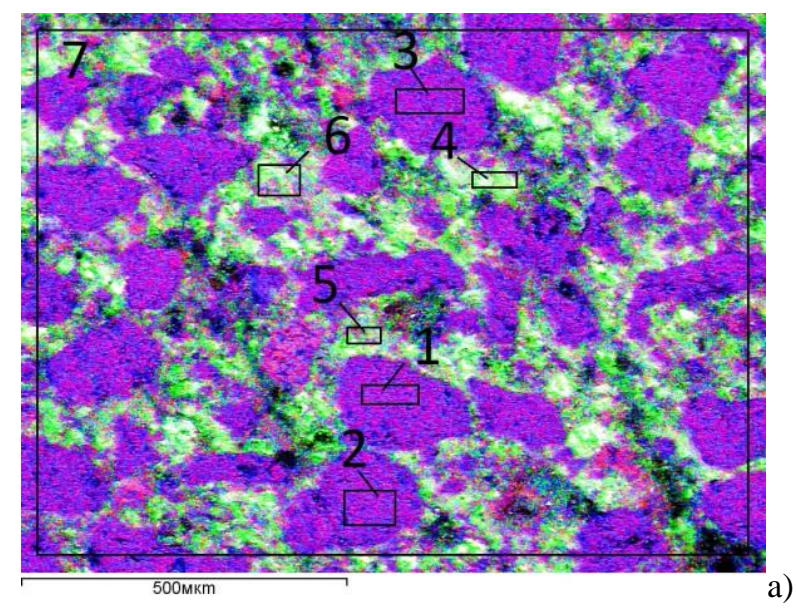

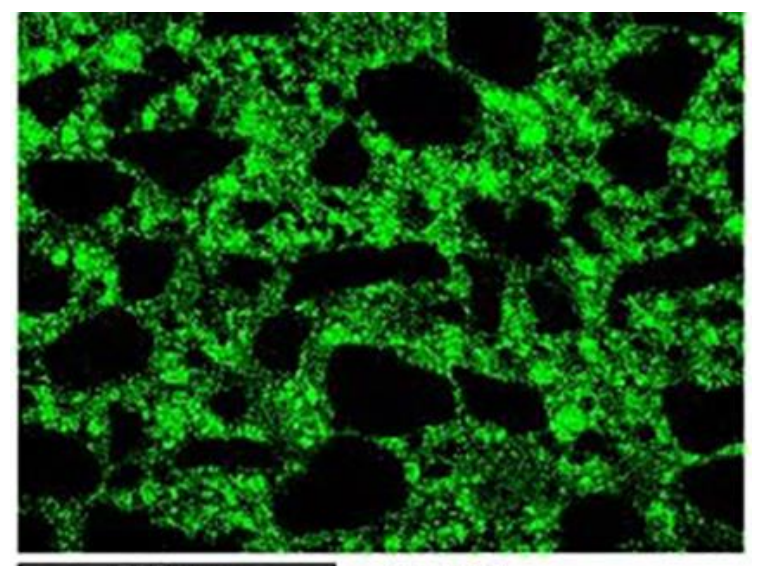

$500 \mathrm{Mkm}$

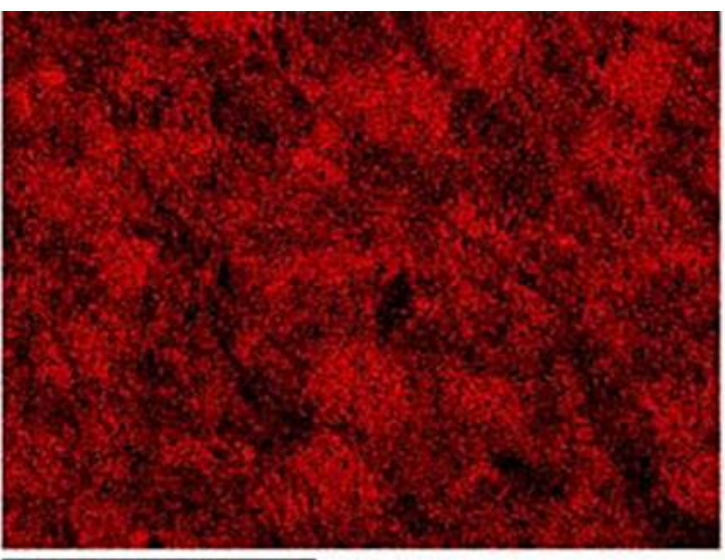

$500 \mathrm{MKm}$

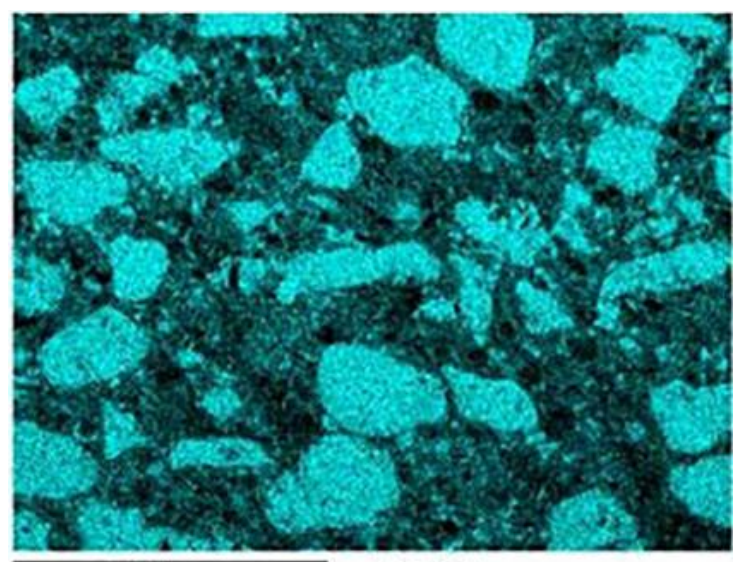

b)

$500 \mathrm{MKm}$

Si Ka1

c)

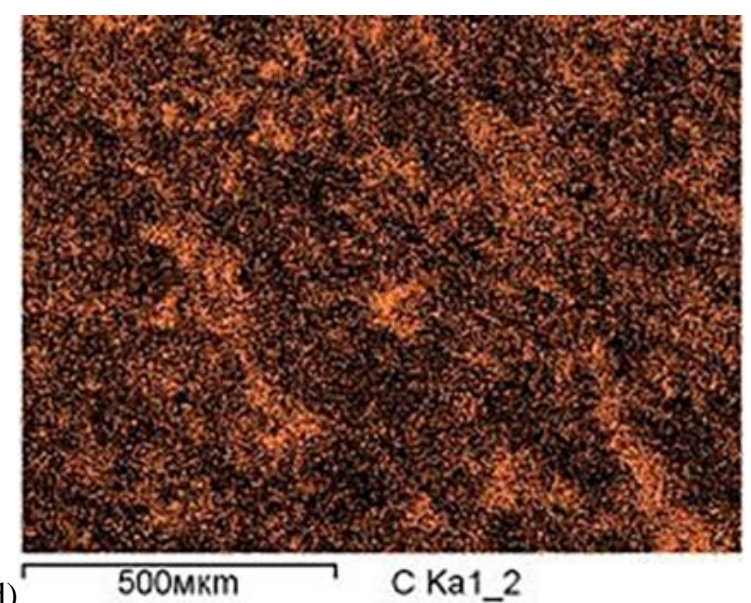

d)

$500 \mathrm{Mkm}$

CKa1_2

Fig. 2. Composition №2. The content of chemical elements in the numbered regions (Table 1) on SEM images (a) and on the surface of chips of cement matrix: $\mathrm{Ca}(\mathrm{b}), \mathrm{Si}(\mathrm{c}), \mathrm{O}(\mathrm{d}), \mathrm{C}(\mathrm{e}) .(\mathrm{x} 250)$. 
compacted for sample № 2 in Fig. 2. Probably, a set of chemically active substances are formed in the process of hydration of clinker minerals during the hardening of concrete, first of all - hydrate of calcium oxide and hydrate of calcium silicate. It is likely that MTK and MS in the concrete compound create the conditions for transformation of unstable and soluble calcium hydroxide into a strong crystalline calcium silicate hydrate (CSH). Thus, the concrete structure is packed and gives an increase in the strength index for sample № 2 .
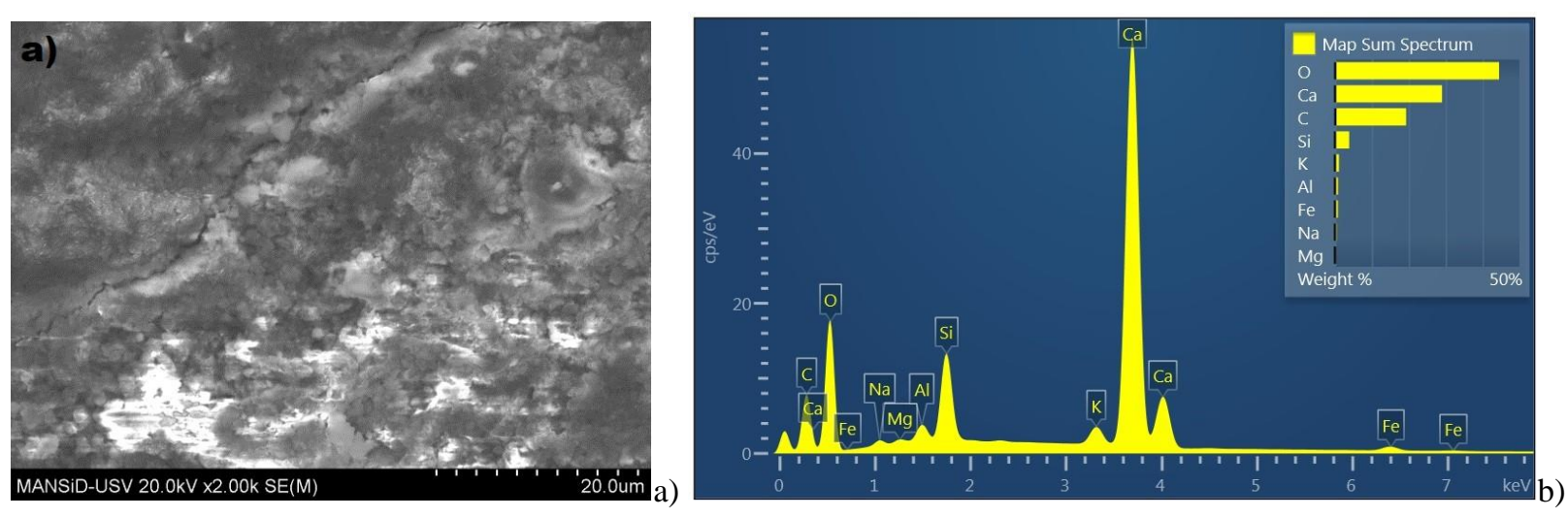

Fig. 3. Chip of concrete sample of composition №1: SEM image of the surface (a); elemental map based on the results of EDX analysis (b).
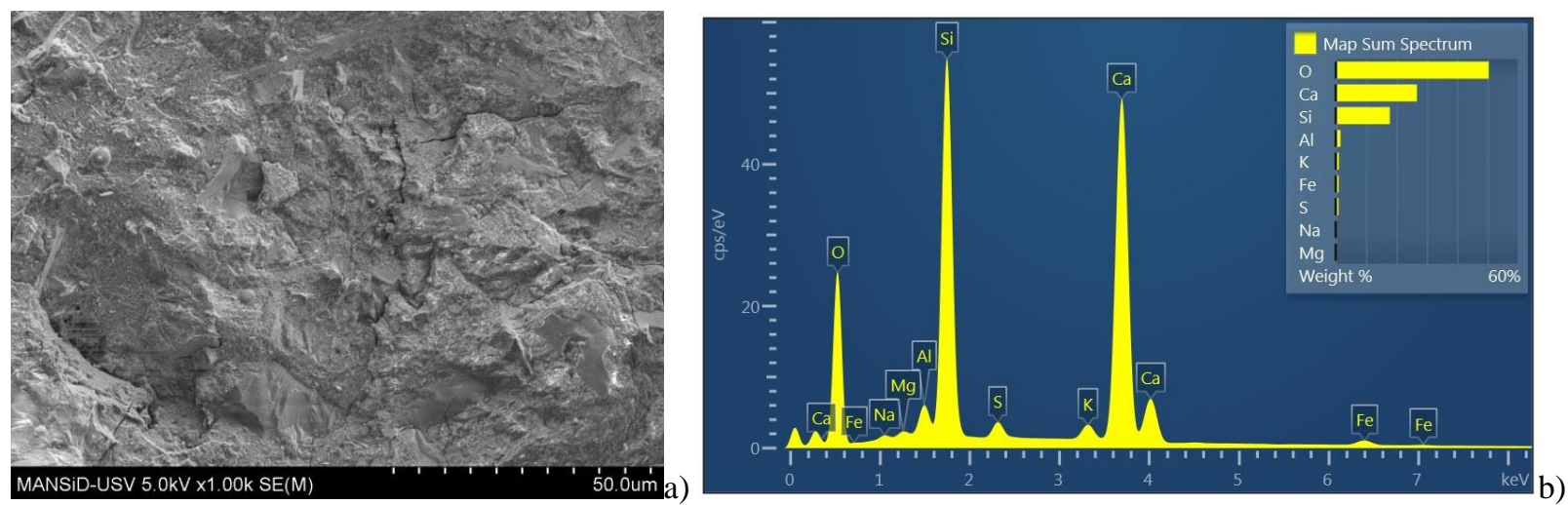

Fig. 4. Chip of concrete sample of composition №2: SEM image of the surface (a); elemental map based on the results of EDX analysis (b).

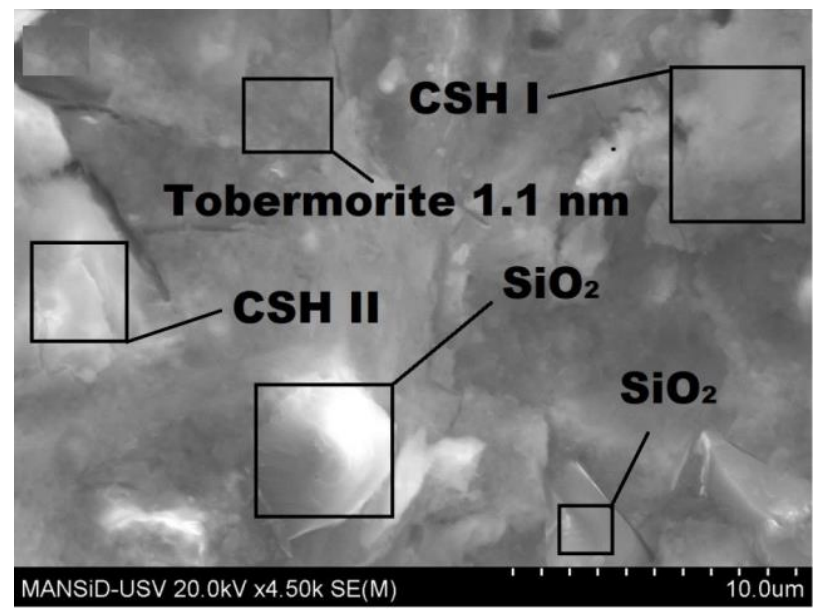

Fig. 5. SEM image of chip microstructure of the cement matrix surface of composition № 2 . 

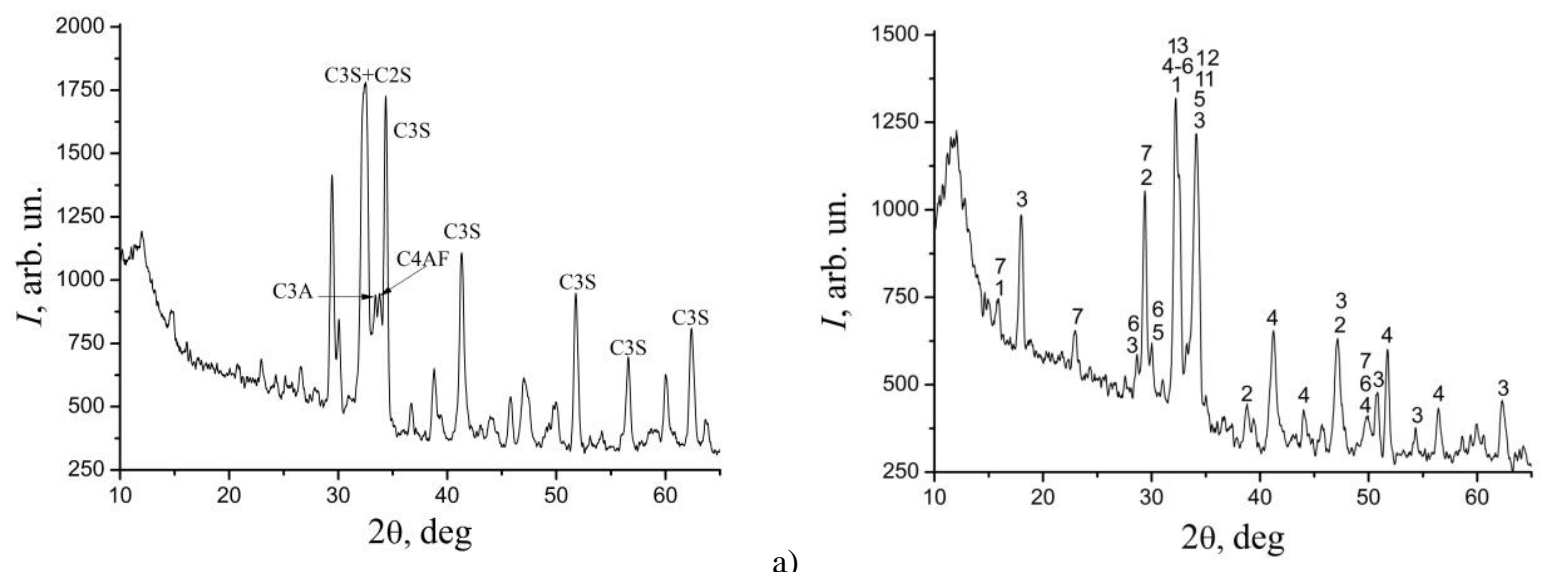

a)

Fig. 6. Diffraction patterns of phase composition of cement containing various clinker minerals (Table 5) (a) and concrete composition №2, numbers mark compounds of cement hydration, MK and MTK (Table 6) (b).

Table 5

Quantitative content (in \%) of main cement phases (Fig. 6,a)

\begin{tabular}{|c|c|c|c|}
\hline № & Clinker minerals & Chemical formula & Content, \% \\
\hline 1 & $\mathrm{C} 3 \mathrm{~S}$ & $\mathrm{Ca}_{3} \mathrm{O}_{5} \mathrm{Si}$ & 22 \\
\hline 2 & $\mathrm{C} 2 \mathrm{~S}$ & $\mathrm{Ca}_{2} \mathrm{O}_{4} \mathrm{Si}$ & 11.6 \\
\hline 3 & $\mathrm{C} 4 \mathrm{FA}$ & $\mathrm{Al}_{2} \mathrm{Ca}_{4} \mathrm{Fe}_{2} \mathrm{O}_{10}$ & 14.5 \\
\hline 4 & $\mathrm{C} 3 \mathrm{~A}$ & $\mathrm{Al}_{2} \mathrm{Ca}_{3} \mathrm{O}_{6}$ & 22 \\
\hline
\end{tabular}

Table 6

The main phase components of composition №2 (Fig. 6b) (CASH - calcium aluminum silicate hydrate,

$\mathrm{CAH}$ - calcium aluminum hydrate)

\begin{tabular}{|c|l|c|c|}
\hline № & \multicolumn{1}{|c|}{$\begin{array}{c}\text { Chemical } \\
\text { formula }\end{array}$} & $d / n$ & Compound \\
\hline 1 & \multicolumn{1}{|c|}{$\mathrm{Al}_{2} \mathrm{Ca}_{6} \mathrm{H}_{66} \mathrm{O}_{49.68} \mathrm{~S}_{3}$} & $0.974,0.563,0.388,0.278,0.303$, & Ettringite \\
2 & $\mathrm{CaCO}_{3}$ & 0.191 & Calcite \\
3 & $\mathrm{Ca}(\mathrm{OH})_{2}$ & $0.491,0.262,0.192$ & Portlantide \\
4 & $\mathrm{Ca}_{3} \mathrm{H}_{2} \mathrm{O}_{7.5} \mathrm{Si}_{1.5}$ & $0.278,0.335,0.181$ & CSH \\
5 & $\mathrm{Ca}_{9} \mathrm{H}_{22} \mathrm{O}_{32} \mathrm{Si}_{6}$ & $1.049,0.262,0.278$ & Jennite \\
6 & $\mathrm{Ca}_{2} \mathrm{H}_{3} \mathrm{O}_{11} \mathrm{Si}_{3}$ & $0.308,0.297,0.351$ & Tobermorite 1,1-HM \\
7 & $\mathrm{Ca}_{2.5} \mathrm{H}_{11} \mathrm{O}_{12.5} \mathrm{Si}_{3}$ & $0.552,0.310,0.301$ & Tobermorite $1,4-\mathrm{HM}$ \\
8 & $\mathrm{Ca}_{5} \mathrm{H}_{10} \mathrm{O}_{22} \mathrm{Si}_{6}$ & $0.307,0.301,0.279$ & Clinotobermorite \\
9 & $\mathrm{Ca}_{2} \mathrm{H}_{2} \mathrm{O}_{5} \mathrm{Si}_{1}$ & $0.287,0.269,0.260$ & CSH \\
10 & $\mathrm{Ca}_{5} \mathrm{H}_{2} \mathrm{O}_{10} \mathrm{Si}_{2}$ & $0.303,0.277,0.256$ & CSH \\
11 & $\mathrm{Al}_{2} \mathrm{CaH}_{10} \mathrm{O}_{21} \mathrm{Si}_{6}$ & $0.305,0.275,0.268$ & CASH \\
12 & $\mathrm{Al}_{2} \mathrm{CaH}_{8} \mathrm{O}_{10} \mathrm{Si}_{12}$ & $0.263,0.262$ & CASH \\
13 & $\mathrm{Al}_{3,5} \mathrm{Ca}_{3} \mathrm{H}_{9,7} \mathrm{O}_{12}$ & $0.276,0.309$ & CAH \\
\hline
\end{tabular}

higher specific surface area of pozzolan particles, which are able to react faster with $\mathrm{Ca}(\mathrm{OH})_{2}$, creating a denser microstructure $[16,20]$.

The list of elements in the Table 3 and their percentage indicates the presence of $\mathrm{CaCO}_{3}$ calcite in the concrete matrix, which was formed as a result of the reaction of calcium oxide with atmospheric carbon dioxide in the presence of moisture and has a spherical structure with low adhesion and cohesion to the cement stone. High concentrations of calcite on chip surfaces are due to the fact that chip of concrete composite structure lays mainly in regions of lower strength with this phase, that is confirmed by the EDX data analysis. The results of EDX spectroscopy let us assume that the higher the dispersion of calcite phase components, the higher the concentration of aluminum atoms and the lower of 
silicon.

A typical X-ray diffraction pattern of cement is shown in Fig. 6a. The diffraction pattern shows the main crystalline phases, which significantly influence the formation of strength characteristics of concrete composites (Fig. 6,b). In particular, to characterize samples №1 and №2 [21] we have chosen typical cement phases with next maxima of intensity in the diffraction pattern (Fig. 6,a) [21]: for phase C3A $2 \theta=33 \mathrm{deg}$, lattice period $d=2.70 \AA \AA$; for phase $\mathrm{C}_{4} \mathrm{AF} 2 \theta=33.3 \mathrm{deg}$, $d=2.64 \AA$, for phase $\mathrm{C} 3 \mathrm{~S}$ intensity maxima are repeated, $d=3.04 \AA$. The experimental X-ray diffraction patterns in Fig. 6 were processed using Match3 software.

Most intensity maxima of $\beta-\mathrm{C}_{2} \mathrm{~S}$ phase are superimposed on the maxima of other clinker minerals, in particular, $\mathrm{C}_{3} \mathrm{~S}$ phase (at $2 \theta=29.38 \mathrm{deg}$ ). Therefore, a maximum of $2 \theta=30.94 \mathrm{deg}(d=2.89 \AA)$ was chosen for this mineral.

The most of the intensity maxima of $\beta-\mathrm{C}_{2} \mathrm{~S}$ phase are superimposed on corresponding maxima of other clinker minerals, in particular $\mathrm{C}_{3} \mathrm{~S}$ phase (at $(2 \theta=33.3 \mathrm{deg}$.). The ratio of the major phases of clinker minerals in cement is shown in table 5 .

The destruction of concrete sample № 2 under pressure of $120 \mathrm{MPa}$ occurred with the formation of cracks with a predominant amount of calcium hydroxides, which are denser and stronger than the structure, which prevails on fractures of sample № 1 with calcite cracks (Fig. 3,a).

All hydration phases in samples of composition № 2 are more evenly distributed than in the first ones. Phase sizes are slightly different according to EDS data, but they are not larger than $\approx 20 \mu \mathrm{m}$. Characteristic destruction of composition №2 sample occurred on trunk cracks, which develop through a larger number of phases, unlike the destruction of composition №1 sample, which cracked mainly along one structure.

According to the X-ray structural and spectral analysis, it follows that a number of reactive phases is formed in a set of samples with a strength of $120 \mathrm{MPa}$ during the process of hydration of clinker minerals and hardening of concrete (table 6). The first of all there are potassium oxide hydrate, calcium silicate hydrate (CSH) and structural gel models such as Jennite and Tobermorite (Fig. 6). Modification of the concrete composite with the MS and MTK complex creates the conditions for transformation of unstable and soluble calcium hydroxide into a strong crystalline calcium silicate hydrate. This compacted concrete structure gives a significant increase in the strength value. In addition, the use of MS in cement dough liquid phase forms a gel of silicon oxide, which subsequently adsorbs free $\mathrm{Ca}^{2+}$ and $\mathrm{OH}$ ions with the formation of weakly crystallized low-basic CSHs (table 6). Under limited conditions low- basic CSHs lead to an increase in the number of gel pores and a decrease in open porosity. Such closed pores prevent the spreading of cracks deeper into the solid, i.e. small closed pores prevent the process of material destruction.

\section{Conclusions}

Modification of the cement matrix with a complex of finely divided additives based on MS and MTK lead preferably to the formation of low-basic calcium hydrosilicates and structural models of the C-S-H gel such as Jennite and Tobermorite with layered structure. These phases are probably formed from the components of $\mathrm{CH}$ and active silica at a ratio of $\mathrm{Ca} / \mathrm{Si}-1.1-1.2$.

The influence of MS on the mechanical properties of concrete in complex with MTK and polycarboxylate ether leads to increase of the strength characteristics of concrete by more than $80 \%$ under the conditions of preservation of technological properties of the mixture. It is likely that the complex of modifiers based on MS and MTK in the concrete compound creates the conditions for conversion of unstable and soluble calcium hydroxide into a strong crystalline calcium silicate hydrate (CSH). This compacted concrete structure gives a significant increase in the strength value.

The formation of such cement gel structural elements as Jennite and Tobermorite, which are inherently nanomaterials since they consist of many separate layers of molecules with different properties, also contributes to the creation of a stronger concrete composite.

Sumariuk O.V. - assistant of the department of Construction Engineering;

Romankevych V.F. - assistant of the department of Construction Engineering;

Halunka O.D. - assistant of the department of Construction Engineering;

Kutsyk O.V. - assistant of the department of Construction Engineering;

Polevetsky V.V. - Associate Professor of the department of construction;

Novikov S.M. - Doctor of Physical and Mathematical Sciences, Professor of Department of Information Technologies and Computer Physics, Head of the department of Construction Engineering;

Fodchuk I.M. - Doctor of Physical and Mathematical Sciences, Professor of Department of Information Technologies and Computer Physics, Dean of Faculty of Architecture, Construction Engineering, and Decorative and Applied Arts.

[1] H. Li, H. Gang, X. Jie, J. Yuan, J. Ou, Composites Part B: Engineering 35(2), 185 (2004) (https://doi.org/10.1016/S1359-8368(03)00052-0)

[2] K. Jayakumar, International Symposium on Ultra High Performance Concrete (Kassel university press GmbH, Kassel, 2004), p. 165.

[3] J. F. Martirena, R. L. Day, B. Middendorf, M. Gehrke, L. Martinez, J. M. Dopico, International Symposium on Ultra High Performance Concrete (Kassel university press GmbH, Kassel, 2004), p. 117. 
[4] O.V. Sumariuk, V. F. Romankevich, I. M. Fodchuk, Nanosystems, Nanomaterials, Nanotechnologies, 16(1), 103 (2018) (https://doi.org/10.15407/nnn).

[5] O.V. Sumariuk, V. F. Romankevich, I. M. Fodchuk, Nanosystems, Nanomaterials, Nanotechnologies 16(1), 117 (2018) (https://doi.org/10.15407/nnn).

[6] V.V. Troyan, V.V. Tovstonis, Construction, materials science, mechanical engineering 47, 661(2008).

[7] H.J.H. Brouwers, H.J. Radix, Self-compacting concrete: the role of the particle (Changsha, Hunan, China, 2005).

[8] D.P. Bentz, O.M. Jensen, Cem. Concr. Comp. 26(6), 677 (2004) (https://doi.org/10.1016/S09589465(03)00045-3).

[9] C. Hoff, D. Eng, The use of lightweight fines for the internal curing of concrete (Clinton: Hoff Consulting LLC, Mississippi, 2002).

[10] E.E. Holt, Early age autogenous shrinkage of concrete (VTT Publications, Espoo, 2001).

[11] I.M. Fodchuk, M.D. Borcha, V.Yu. Khomenko, S.V. Balovsyak, V.M. Tkach, O.O. Statsenko, Journal of Superhard Materials, 38(4), 271 (2016) (https://doi.org/10.3103/S1063457616040080).

[12] M.D. Borcha, S.V. Balovsyak, I.M. Fodchuk, V.Yu. Khomenko, O.P. Kroitor, V.N. Tkach, Journal of Superhard Materials 35(5), 284 (2013) (https://doi.org/10.3103/S1063457613050031).

[13] I.M. Fodchuk, I.I. Gutsuliak, V.V. Dovganiuk, A.O. Kotsyubynskiy, U. Pietsch, N.V. Pashniak, O.Yu. Bonchyk, I.M. Syvorotka, P.M. Lytvyn, Applied Optics 55(12), B144 (2016) (https://doi.org/10.1364/AO.55.00B144).

[14] M.D. Borcha, M.S. Solodkyi, S.V. Balovsyak, V.N. Tkach, I.I. Hutsuliak, A.R. Kuzmin, O.O Tkach, V.P. Kladko, O.Y. Gudymenko, O.I. Liubchenko, Z. Świątek, Semiconductor Physics, Quantum Electronics and Optoelectronics 22(4), 381 (2019) (https://doi.org/10.15407/spqeo22.04.381).

[15] D. Stephan, R. Krelaus, M. Schmidt, Proceedings of the 2nd International Symposium on Ultra High Performance Concrete (Kassel University Press, Kassel, 2008), p. 375.

[16] M. Sanytsky, B. Rusyn, J. Halbiniak, J. Szymańska, Budownictwo o Zoptymalizowanym Potencjale Energetycznym 2(12), 96 (2013).

[17] DIN EN 206-1/DIN 1045-2 gilt für Beton, der für Ort beton bauwerke, vorgefertigte Bauwerke sowie Fertigteile für Gebäude und Ingenieur bauwerke verwendet wird.

[18] DSTU B B.2.7-96-2000 Smesi Betonnyye: Tekhnicheskie Usloviya [Concrete Mixtures: Technical Conditions].

[19] DIN EN 197-1, Zement - Teil 1: Zusammensetzung, Anforderungen und Kon-formitätskriterien von Normalzement; Deutsche Fassung (EN 197-1:2000, Ausgabe: Nov. 2000).

[20] K. Wille, A.E. Naaman, G.J. Parra-Montesinos, ACI Materials Journal 108(1), 46 (2011) (https://doi.org/10.14359/51664215).

[21] B-S. Kim, S. Kim, Y-J. Kim, S. Park, K-T,Koh, C. Joh, International Symposium on Ultra High Performance Concrete (Kassel university press GmbH, Kassel, 2012), p. 865.

\author{
О.В. Сумарюк, В.Ф. Романкевич, О.Д. Галунка, О.В. Куцик, В.В. Полевецький, \\ С.М. Новіков, I.М. Фодчук
}

\title{
Вплив поліфункціональних наномодифікаторів на мікроструктуру бетонних композитів високої міцності і щільності
}

Чернівецький національний університет імені Юрія Федьковича, м. Чернівиі, Украӥна, е-таil: ifodchuk@ukr.net

Досліджено закономірності структуроутворення високофункціональних бетонів, які полягають у формуванні впорядкованої, низькопористої, дрібнокристалічної мікроструктури цементуючої матриці, в тому числі за рахунок пуцоланових реакцій у неклінкерній частині в'яжучого з утворенням додаткової кількості низькоосновних гідросилікатів кальцію.

Ключові слова: бетон, ультрадисперсні модифікатори, кремнезем, метакаолін, кварцова пудра, скануюча електронна мікроскопія. 